\title{
Potensi Ekstrak Etanol Bawang Dayak (Eleutherine americana Merr.) sebagai Protektor Diameter Tubulus Seminiferus Mencit (Mus musculus) Balb/C yang di Induksi Timbal Asetat
}

\author{
Paramita Ratna Gayatri', Sri Agus Sudjarwo ${ }^{2}$, Reny I'tishom ${ }^{3}$ \\ ${ }^{1}$ Magister Ilmu Kesehatan Reproduksi FK Universitas Airlangga Surabaya ${ }^{2}$ Fakultas \\ Kedokteran Hewan Universitas Airlangga Surabaya \\ ${ }^{3}$ Departemen Biologi Medik FK Universitas Airlangga Surabaya \\ Email : paramitaratna11@gmail.com ${ }^{1}$, ags158@yahoo.com ${ }^{2}, \underline{\text { ritishom@fk.unair.ac.id }}^{3}$
}

\begin{abstract}
Abstrak
Timbal merupakan salah satu bahan pencemar udara yang berpengaruh pada kesehatan organ reproduksi pria. Polusi udara oleh logam berat ini menyebabkan terbentuknya Reactive Oxygen Species dan penurunan simpanan antioksidan tubuh.

Penelitian ini bertujuan mengetahui potensi ekstrak etanol bawang dayak untuk mempertahankan diameter tubulus seminiferus pada mencit yang diinduksi timbal asetat.

Jenis penelitian ini adalah eksperimental murni laboratorik (true experimental) dengan rancangan penelitian Posttest Only Control Group Design. Subyek penelitian adalah 30 mencit (Mus musculus) jantan strain Balb/C yang diinduksi timbal asetat $0,75 \mathrm{mg} / \mathrm{KgBB} / \mathrm{hari}$ dan dibagi menjadi 5 kelompok perlakuan, yaitu kelompok kontrol negatif (KO), kelompok kontrol positif (K1), dan kelompok perlakuan dengan pemberian ekstrak bawang 30mg/KgBB/hari (K2), 60mg/KgBB/hari (K3), 120mg/KgBB/hari (K4). Pada hari ke 39, hewan coba dikorbankan untuk diukur diameter tubulus seminiferusnya.

Hasil penelitian menunjukkan tidak ada perbedaan bermakna diameter tubulus seminiferus kelompok kontrol dan perlakuan. Kesimpulan penelitian ini ekstrak etanol bawang dayak tidak mempengaruhi diameter tubulus seminiferus mencit yang di induksi timbal asetat
\end{abstract}

Kata kunci : ekstrak etanol bawang dayak, diameter tubulus seminiferus, timbal asetat 


\section{PENDAHULUAN}

Indonesia merupakan salah satu negara berkembang yang memiliki tingkat percepatan pertumbuhan transportasi yang tinggi, dampak negatifnya yaitu menyebabkan tingginya tingkat pencemaran udara (Widowati dkk., 2008). Hasil penelitian Lembaga Penerbangan dan Antariksa Nasional (LAPAN) mengenai pencemaran udara di perkotaan, emisi transportasi terbukti sebagai penyumbang pencemaran udara tertinggi di Indonesia, yakni sekitar 85\% (Gusnita, 2012). Pencemaran udara mengandung berbagai logam berat, salah satunya timbal yang bersumber dari pembakaran bahan bakar kendaraan bermotor dan emisi industri (Mardiani, 2008). Pencemaran timbal oleh asap kendaraan bermotor, 30-40\% yang terabsorbsi akan masuk ke dalam aliran darah lalu 95\% timbal dalam darah tersebut di ikat oleh eritrosit. (Palar, 2008). Ambang batas kadar timbal dalam darah menurut WHO adalah 400 $\mu \mathrm{g} / \mathrm{dl}$ (I'tishom dkk, 2011).

Timbal adalah bahan yang dapat meracuni lingkungan dan mempunyai dampak pada seluruh sistem di dalam tubuh. Paparan timbal merupakan toksin lingkungan persisten yang dapat menyebabkan gangguan neurologi, hematologi, gastrointestinal, reproduksi, sirkulasi, dan imunologi (Patrick, 2006). Timbunan timbal di dalam sel darah merah dan di jaringan lunak di duga paling bertanggungjawab terhadap efek toksiknya bagi tubuh (Patocka dan Cerny, 2003). Penelitian yang dilakukan pada pria yang terpapar emisi gas buang kendaraan bermotor membuktikan bahwa paparan emisi gas buang kendaraan bermotor menurunkan motilitas spermatozoa (Lubis, 2009). Penelitian pada hewan coba didapatkan bukti bahwa paparan timbal dapat menekan aksis hypothalamus-hipofisa-testis, sehingga mengakibatkan histologi testis, morfologi spermatozoa dan hubungan berbagai sel didalam testis terganggu (Sharma dan Garu, 2011).

Timbal sebagai radikal bebas dapat menyebabkan kerusakan melalui dua mekanisme, yaitu 1) pembentukan ROS, antara lain hiperoksida, oksigen anglet dan hidrogen peroksida; dan 2) penurunan simpanan anti oksidan tubuh. Pada setiap sistem biologis dimana terjadi produksi radikal bebas berlebih, simpanan anti oksidan akan menurun (Patrick, 2006).
Dampak negatif radikal bebas pada kesehatan reproduksi dapat dicegah dengan pemberian antioksidan. Sumber antioksidan alami lebih banyak dipilih karena harga terjangkau dan memiliki sedikit efek samping (Flora et al., 2012). Bawang dayak merupakan tanaman yang berpotensi sebagai sumber antioksidan alami (Ernawati dan Nurliani, 2012). Kandungan fitokimia yang dimiliki tanaman bawang dayak antara lain alkaloid, glikosida, flavonoid, fenolik, steroid, tanin (Galingging, 2007) serta kuinon (Nawawi et al., 2007). Tanaman khas Kalimantan Tengah ini mengandung senyawa fenolat golongan naftokuinon (Alves et al., 2003; Hara et al., 1997; Han et al., 2008; Nielsen \& Wege, 2006). Naftokuinon memiliki bioaktivitas sebagai antioksidan dan anti kanker (Firdaus, 2006). Aktivitas antioksidan yang kuat pada ekstrak etanol bawang dayak dibuktikan dengan nilai $\mathrm{IC}_{50}$

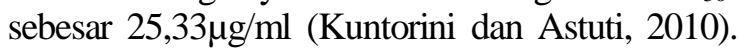
Kandungan senyawa fenolik dalam bawang dayak diduga dapat membentuk ikatan senyawa radikal antioksidan lebih stabil dan tidak berbahaya bagi sel tubuh (Prior dan Schaich, 2005). Umbi bawang dayak dipercaya mengandung berbagai senyawa aktif yang ampuh menggempur berbagai macam penyakit. Sebut saja senyawa golongan naftokuinon yang terkandung dalam umbi tanaman ini. Oleh karena itu wajar bila umbi tanaman ini terkenal sebagai obat untuk berbagai macam penyakit. Senyawa naftokuinon biasanya digunakan antara lain sebagai antimikroba dan antioksidan (Kuntorini, 2013).

Tujuan penelitian ini untuk membuktikan ekstrak etanol bawang dayak (Eleutherine americana Merr.) mampu mempertahankan kadar hormon testosteron, diameter dan tebal epitel tubulus seminiferus mencit (Mus musculus) Balb/C yang di induksi timbal asetat.

\section{METODE}

\section{Alat Penelitian}

Kandang mencit, timbangan, disposible syringe, sonde, set alat bedah steril, object glass, mikroskop cahaya

\section{Bahan Penelitian}

Bahan yang digunakan adalah mencit jantan (Mus musculus) Balb/C Bahan pemeliharaan mencit : pelet untuk makanan hewan coba. Bahan untuk 
perlakukan : ekstrak bawang dayak (Eleutherine americana Merr.), timbal asetat, aquadest, NaCMC 0,5\%. Bahan pembedahan : alkohol 70\%, buffer formalin. Bahan fiksasi jaringan : alkohol $70 \%, 80 \%$, 96\%, parafin cair. Bahan pewarnaan histologis : hemaktosilin, eosin

\section{Pembuatan Ekstrak Bawang Dayak}

a) Bawang dayak sebanyak $10 \mathrm{~kg}$ dikupas kulitnya, dikeringkan kemudian dihaluskan.

b) Serbuk bawang dayak kemudian ditimbang sejumlah 500 gram, dimasukkan ke dalam alat maserasi, ditambahkan etanol $97 \%$ sambil diaduk hingga cairan etanol terendam $1 \mathrm{~cm}$ di atas permukaan sampel.

c) Ekstraksi selama 3x24 jam, pergantian pelarut dilakukan sekali sehari.

d) Pelarut diuapkan menggunakan vacuum rotary evaporator pada suhu 40 c sampai tidak menguap lagi.

e) Filtrat diuapkan kembali di atas waterbath dan ditimbang berat ekstrak yang dihasilkan (Ernawati \& Anni, 2012).

\section{Hewan coba dan Perlakuan}

Subyek penelitian adalah 30 mencit (Mus Musculus) jantan strain Balb/C dengan kriteria berumur 6-8 minggu, berat badan 25-35 gram, kondisi fisik sehat yang ditandai dengan gerakan lincah dan nafsu makan baik. Mencit dibagi menjadi 5 kelompok, yaitu 2 kontrol dan 3 perlakuan yang masing - masing berjumlah 5 ekor mencit. Perlakuan yang diberikan pada hewan coba adalah:

a) Kelompok kontrol negatif (K0) diberi NaCMC 0,5\% selama 38 hari

b) Kelompok kontrol positif (K1) diberi NaCMC $0,5 \%$ selama 3 hari kemudian di induksi timbal asetat dosis $0,075 \mathrm{~g} / \mathrm{KgBB} / \mathrm{hari}$ selama 35 hari

c) Kelompok perlakuan 1 (K2) diberi ekstrak bawang dayak $30 \mathrm{mg} / \mathrm{KgBB}$ selama 3 hari kemudian diinduksi timbal asetat dosis $0,075 \mathrm{~g} / \mathrm{KgBB} / \mathrm{hari}$, satu jam setelahnya diberi ekstrak bawang dayak $30 \mathrm{mg} / \mathrm{KgBB}$ selama 35 hari

d) Kelompok perlakuan 2 (K3) diberi ekstrak bawang dayak $60 \mathrm{mg} / \mathrm{KgBB}$ selama 3 hari kemudian diinduksi timbal asetat dosis $0,075 \mathrm{~g} / \mathrm{KgBB} / \mathrm{hari}$, satu jam setelahnya diberi ekstrak bawang dayak $60 \mathrm{mg} / \mathrm{KgBB}$ selama 35 hari

e) Kelompok perlakuan 3 (K4) diberi ekstrak bawang dayak $120 \mathrm{mg} / \mathrm{KgBB}$ selama 3 hari kemudian diinduksi timbal asetat dosis $0,075 \mathrm{~g} / \mathrm{KgBB} / \mathrm{hari}$, satu jam setelahnya diberi ekstrak bawang dayak $120 \mathrm{mg} / \mathrm{KgBB}$ selama 35 hari.

Pemberian ekstrak bawang dayak dan timbal asetat pada hewan coba dilakukan per oral menggunakan sonde. Pada hari ke 39 semua subyek penelitian dikorbankan. Hewan coba diterminasi dengan pembiusan menggunakan kloroform kemudian dilakukan pembedahan untuk diambil testis. Penelitian ini telah mendapatkan sertifikat kelaikan etik dari Komite Etik Penelitian Fakultas Kedokteran Universitas Airlangga Surabaya.

\section{Pengukuran Diameter Tubulus Seminiferus}

Diameter tubulus seminiferus diukur dengan membuat preparat dari potongan testis. Pembuatan preparat menggunakan metode parafin, diwarnai dengan hemaktosilin dan eosin. Kemudian dilihat di bawah mikroskop cahaya. Pengukuran dilakukan dengan mengukur diameter tubulus seminiferus terpanjang dan terpendek dalam satuan mikron kemudian di rerata (Agustina, 2015).

\section{Analisis Statistik}

Data hasil penelitian disajikan dalam bentuk mean dan standart deviasi juga histogram. Penilaian distribusi data menggunakan uji Kolmogorov-Smirnov. Distribusi data normal apabila nilai $\mathrm{p} \geq 0,05$. Data yang berdistribusi normal kemudian dianalisis dengan uji one way ANOVA. Untuk mengetahui kelompok mana yang berbeda secara bermakna, maka dilakukan analisis Post-Hoc.

\section{HASIL}

Hasil pengukuran histologis diameter tubulus seminiferus dapat dilihat pada gambar 1 sampai dengan 


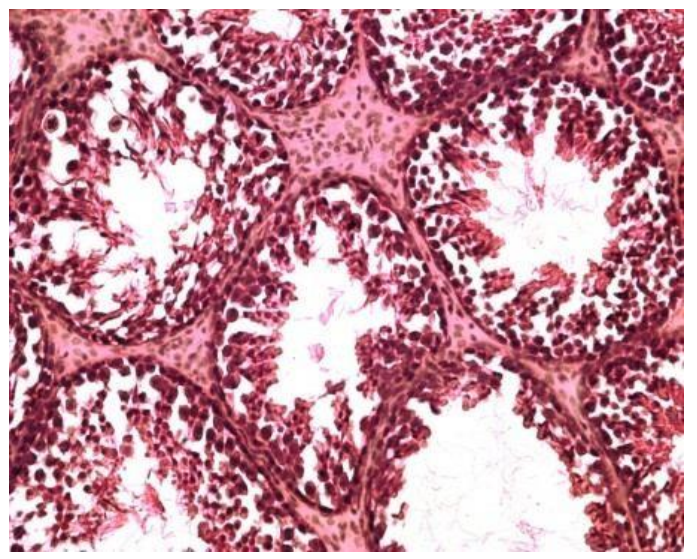

Gambar 1.1 Diameter tubulus seminiferus mencit (Mus musculus) Balb/C kelompok kontrol negatif (K0) yang diberi $\mathrm{Na}-\mathrm{CMC} 0,5 \%$ selama 38 hari

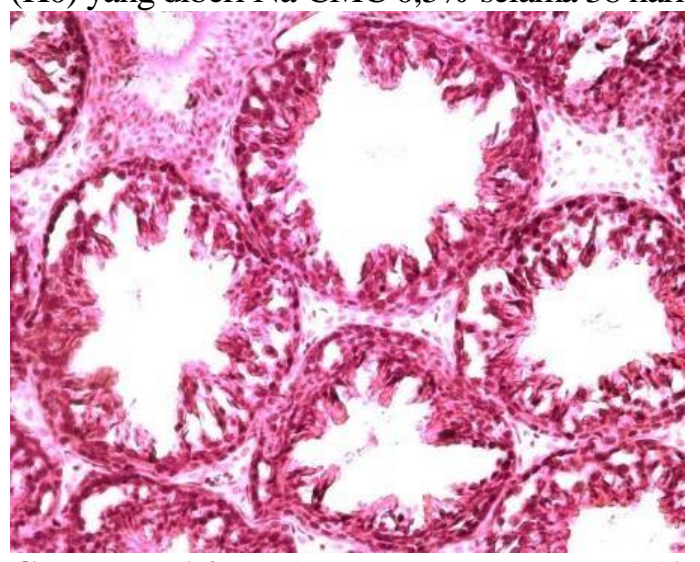

Gambar 1.2. Diameter tubulus seminiferus mencit (Mus musculus) Balb/C kelompok kontrol positif (K1) yang diberi Na-CMC 0,5\% selama 3 hari kemudian di induksi timbal asetat dosis 0,075g/KgBB/hari selama 35 hari

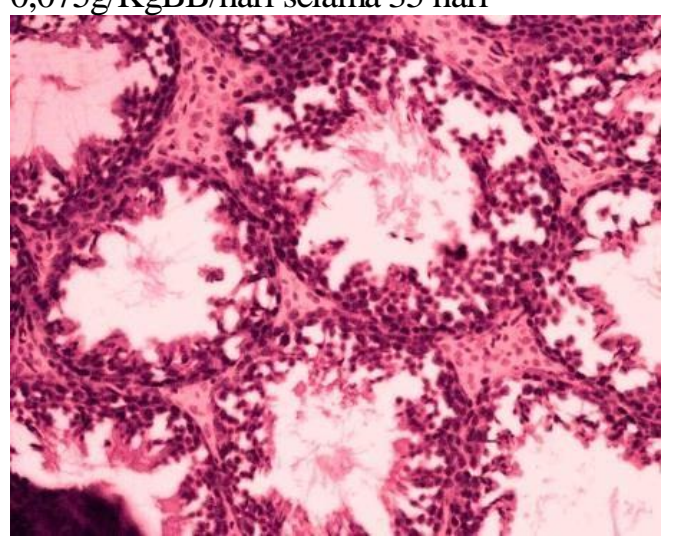

Gambar 1.3. Diameter tubulus seminiferus mencit (Mus musculus) Balb/C kelompok perlakuan $1(\mathrm{~K} 2)$ yang diberi ekstrak bawang dayak $30 \mathrm{mg} / \mathrm{KgBB}$ selama 3 hari kemudian diinduksi timbal asetat dosis $0,075 \mathrm{~g} / \mathrm{KgBB} / \mathrm{hari}$, satu jam setelahnya diberi ekstrak bawang dayak $30 \mathrm{mg} / \mathrm{KgBB}$ selama 35 hari

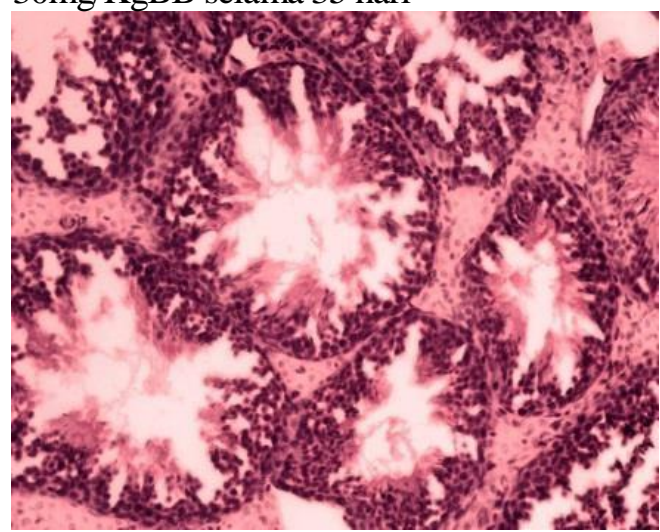

Gambar 1.4. Diameter tubulus seminiferus mencit (Mus musculus) Balb/C kelompok perlakuan 2 (K3) yang diberi ekstrak bawang dayak $60 \mathrm{mg} / \mathrm{KgBB}$ selama 3 hari kemudian diinduksi timbal asetat dosis $0,075 \mathrm{~g} / \mathrm{KgBB} / \mathrm{hari}$, satu jam setelahnya diberi ekstrak bawang dayak $60 \mathrm{mg} / \mathrm{KgBB}$ selama 35 hari

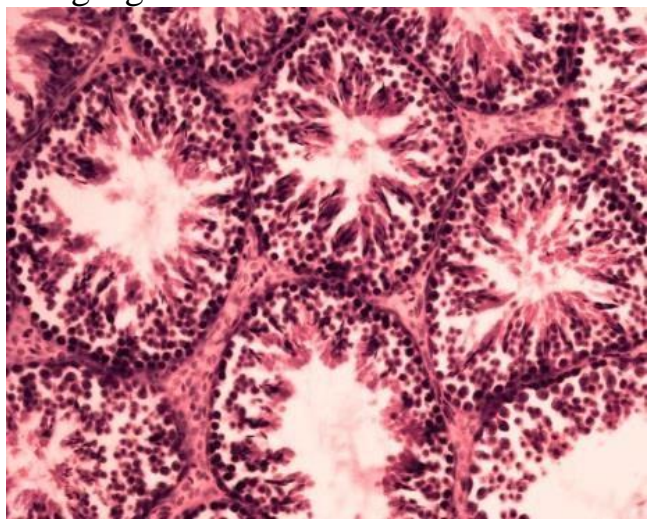

Gambar 1.5. Diameter tubulus seminiferus mencit (Mus musculus) Balb/C kelompok perlakuan 2 (K3) yang diberi ekstrak bawang dayak $120 \mathrm{mg} / \mathrm{KgBB}$ selama 3 hari kemudian diinduksi timbal asetat dosis $0,075 \mathrm{~g} / \mathrm{KgBB} / \mathrm{hari}$, satu jam setelahnya diberi ekstrak bawang dayak $120 \mathrm{mg} / \mathrm{KgBB}$ selama 35 hari.

Data hasil pengukuran diameter tubulus seminiferus mencit disajikan dalam bentuk mean dan standart deviasi sesuai dengan tabel 1 . Penilaian distribusi data menggunakan uji Kolmogorov-Smirnov. Distribusi data normal apabila nilai $\mathrm{p} \geq 0,05$. Berdasarkan hasil perhitungan menunjukkan bahwa variabel diameter tubulus seminiferus mempunyai distribusi data normal dengan nilai $\mathrm{p}=0,999$

Data variabel diameter tubulus seminiferus berdistribusi normal kemudian dianalisis dengan 
uji one way ANOVA dengan hasil tidak didapatkan perbedaan bermakna $(p>0,05)$ antara kelompok kontrol dengan kelompok perlakuan.

Tabel 2. Efek protektor ekstrak etanol bawang dayak (Eleutherine americana Merr.) terhadap diameter tubulus seminiferus mencit (Mus musculus) Balb/C yang di induksi timbal asetat

$\begin{array}{ll} & \text { Kadar Hormon } \\ \text { Kelompok } & \text { Testosteron (ng/dl) } \\ & \text { Rerata } \pm \text { SD }\end{array}$

\begin{tabular}{ll}
\hline Kontrol negatif & $5,5^{\mathrm{a}} \pm 1,37$ \\
\hline Kontrol positif & $2,99^{\mathrm{b}} \pm 1,18$ \\
\hline Ekstrak Bawang Dayak & $5,28^{\mathrm{a}} \pm 2,3$ \\
30mg/KgBB/hari & \\
\hline $\begin{array}{l}\text { Ekstrak Bawang Dayak } \\
\text { 60mg/KgBB/hari }\end{array}$ & $5,3^{\mathrm{a}} \pm 0,71$ \\
\hline $\begin{array}{l}\text { Ekstrak Bawang Dayak } \\
\text { 120mg/KgBB/hari }\end{array}$ & $4,2^{\mathrm{ab}} \pm 1,92$ \\
\hline
\end{tabular}

Huruf superscript yang berbeda,menunjukkan perbedaan bermakna pada $\mathrm{p}<0,05$

Histogram efek ekstrak etanol bawang dayak (Eleutherine americana Merr) terhadap diameter tubulus seminiferus mencit (Mus musculus) $\mathrm{Balb} / \mathrm{C}$ yang di induksi timbal asetat dapat dilihat pada gambar 2.

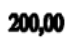

150,00

100,00

50,00

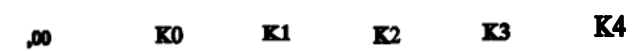

Gambar 2. Efek protektor ekstrak etanol bawang dayak (Eleutherine americana Merr.) terhadap diameter tubulus seminiferus mencit (Mus musculus) Balb/C yang di induksi timbal asetat. K0 : kelompok kontrol negatif; K1 : kelompok kontrol positif; K2 : kelompok pemberian ekstrak bawang dayak 30mg/KgBB/hari; K3 : kelompok pemberian ekstrak bawang dayak $60 \mathrm{mg} / \mathrm{KgBB} / \mathrm{hari}$; K4 : kelompok pemberian ekstrak bawang dayak $120 \mathrm{mg} / \mathrm{KgBB} / \mathrm{hari}$

\section{PEMBAHASAN}

Hasil penelitian menunjukkan bahwa paparan timbal asetat mampu menurunkan diameter tubulus seminiferus seperti yang terlihat di histogram pada gambar 2 yang menunjukkan diameter tubulus seminiferus mencit pada kelompok kontrol positif (K1) lebih rendah daripada kelompok kontrol negatif (K0).

Hasil ini sesuai dengan penelitian Corpas et al., (2001) yang melaporkan pengurangan ketebalan epitel dan diameter tubulus seminiferus yang merupakan akibat dari timbal dalam mereduksi jumlah spermatogonia dan spermatosit. Peneliti lain menemukan bahwa paparan timbal pada mencit juga menyebabkan kerusakan dan pengurangan jumlah tubulus seminiferus dan sel germinal (Garu et al. 2011).

Penurunan diameter tubulus seminiferus dalam penelitian ini disebabkan timbal yang masuk ke dalam tubuh melalui inhalasi dan pencernaan, selanjutnya akan berikatan dengan sel darah merah. Akumulasi timbal dalam sel darah merah menyebabkan inhibisi $\delta$-ALAD (delta aminolevulinic acid dehidratse). Inhibisi $\delta$-ALAD menyebabkan peningkatan ALA (delta aminolevulinic acid). Peningkatan ALA menyebabkan terbentuknya ROS (Reactive Oxygen Species). Pada setiap keadaan dimana terjadi produksi ROS berlebih, maka simpanan anti oksidan tubuh akan menurun. Apabila rasio antara paparan radikal bebas atau oksidan lebih besar daripada antiradikal bebas atau antioksidan. maka akan terjadi stress oksidatif. Terjadinya stres oksidatif menyebabkan gangguan pada hipotalämus yaitu penurunan $\mathrm{GnRH}$ (Gonadotropin Releasing Hormone), penekanan sekresi GnRH yang dihasilkan hipotalamus oleh timbal (Sokol et al., 2002). Penekanan sekresi $\mathrm{GnRH}$ ini menyebabkan penurunan sekresi FSH dan LH. LH berperan untuk menstimulasi sel Leydig untuk menghasilkan hormon testosteron, FSH berfungsi dalam menstimulasi_sel Sertoli menghasilkan Androgen Binding Protein (ABP) untuk mengikat hormon testosteron dalam memacu perkembangan spermatogonium. Penurunan testosteron dan FSH akan menganggu sel germinal untuk berproliferasi, berdiferensiasi dan metabolisme sel. Dampaknya mempengaruhi struktur testis, diantaranya diameter tubulus seminiferus dan sel - sel spermatogenik (Apriliani $\mathrm{dkk}$,

2013). 
Timbal yang masuk ke dalam tubuh akan terakumulasi di testis, epididimis, vas derefen, vesikel seminalis dan semen (Chowdhury, 2009). Hal ini akan mengakibatkan testis menjadi atrofi karena kehilangan sel spermatogenik, merusak bentuk dan menurunkan diameter tubulus seminiferus (Adibmoradi et al., 2015; Lamondo et al., 2014). Penurunan diameter tubulus seminiferus akibat penurunan jumlah sel spermatogonia, jumlah sel Sertoli, jumlah sel germinal (Garu et al., 2011).

Namun hasil statistik pada tabel 2 menunjukkan tidak ada perbedaan bermakna pada kelompok kontrol dan kelompok perlakuan juga Hal ini dimungkinkan karena terbatasnya waktu paparan timbal pada mencit. Penelitian Sokol et al., (2002) menyebutkan bahwa terganggunya sinyal di dalam dan diantara hipotalamus dan kelenjar hipofise tikus oleh paparan timbal bergantung pada kadar dan durasi pajanan timbal. Verstraeten et al., (2008) juga menyebutkan bahwa toksisitas timbal tergantung dari besarnya dosis dan lamanya paparan. Dengan demikian pemberian timbal asetat selama 35 hari masih memberikan efek kerusakan tahap awal, karena kadar akumulasinya belum sepenuhnya mencukupi untuk merusak sel Leydig. Jika timbal

\section{DAFTAR PUSTAKA}

Agustina SNM. 2015. Efek Pemberian Ekstrak Teh Hijau (Camellia Sinensi) terhadap Analisis Semen, Diameter Tubulus Seminiferus dan Kadar Malondialdehyde (MDA) Testis Mencit Balb/C Setelah Dipapar Monosodium Glutamate (MSG). Tesis. Surabaya : Universitas Airlangga. Tidak Dipublikasikan.

Alves TMA, Helmut K, dan Carlos LZ. 2003. Eleutherinone A Novel Fungitoxic Naphtoquinone from Eleutherine Bulbosa (Iridiceae). Memórias do Instituto Oswaldo Cruz Vol. 98, No. $5: 709-712$.

Apriliani $\mathrm{M}$, Nurcahyani $\mathrm{N}$ dan Busman $\mathrm{H}$. 2013. Efek Pemaparan Kebisingan Terhadap Jumlah Sel $\quad-$ Sel Spermatogenik dan Diameter Tubulus Seminiferus Mencit (Mus musculus L.). Seminar Nasional Sains \& diberikan pada durasi waktu yang lebih lama, maka akumulasi timbal asetat semakin banyak dan kemungkinan pengaruhnya terhadap testis semakin nyata.

\section{KESIMPULAN DAN SARAN}

\section{Kesimpulan}

Ekstrak etanol bawang dayak (Eleutherine americana Merr.) terbukti tidak mempengaruhi diameter tubulus seminiferus mencit (Mus musculus) Balb/C yang dipapar timbal asetat

\section{Saran}

Perlu dilakukan penelitian lanjutan tentang efek terapi ekstrak etanol bawang dayak (Eleutherine americana Merr.) dengan waktu minimal 1,5 siklus untuk menghilangkan efek spermatogenesis pada siklus sebelumnya.

\section{UCAPAN TERIMAKASIH}

Terima kasih tak terhingga dan penghargaan yang setinggi - tingginya penulis ucapkan kepada Prof. Sri Agus Sudjarwo, drh., Ph.D selaku pembimbing I, Dr. Reny I'tishom, M.Si selaku pembimbing II atas semua saran ilmiahnya dan semua pihak yang membantu dalam menyelesaikan artikel ilmiah ini.

Teknologi V, Lampung : Lembaga Penelitian Universitas Lampung.Widowati W, Sastiono A, Jusuf R. 2008. Efek Toksik Logam Pencegahan dan Penanggulangan Pencemaran.Yogyakarta : ANDI.

Chowdhury AR. 2009. Recent Advances in Heavy Metals Induced Effect on Male Reproductive Function-A Retrospective. Al Ameen Journal Medicine Science. Vol 2, No. 2 : 37-42.

Corpas I, Castillo M, Marquina D, dan Benito MJ. 2001. Lead Intoxication in Gestational and Lactation Periods Alters the Development of Male Reproductive Organs. Ecotoxicology and Environmental Safety. 53 : 259-266.

Ernawati, Nurliani A. 2012. Efek Antioksidan Ekstrak Etanol Bulbus Bawang Dayak (Eleutherine Americana Merr) terhadap Struktur 
Jurnal Biosains Pascasarjana Vol. 19 (2017) pp

(C)(2017) Sekolah Pascasarjana Universitas Airlangga, Indonesia

Mikroanatomi Tubulus Seminiferus

Testis Tikus yang Dipapar Asap

Rokok. Sains dan Terapan Kimia.

Vol.6, No.2 : 93-100.

Flora G, Gupta D, Tiwari A. 2012. Toxicity of Lead: A Review With Recent Updates. Interdiscip Toxicol. Vol. 5, No. 2: 47-58.

Galingging RY. 2009. Bawang Dayak (Eleutherine Palmifolia) Sebagai Tanaman Obat Multifungsi. Warta Penelitian dan Pengembangan. Vol. 15 , No. $3: 2-4$.

Garu U, Sharma R \& Barber I. 2011. Effect of Lead Toxicity on Developing Testis of Mice. IJPSR. Vol. 2, No. 9: 24032407.

Gusnita D. 2012. Pencemaran Logam Berat Timbal $(\mathrm{Pb})$ di Udara dan Upaya Penghapusan Bensin Bertimbal. Berita Dirgantara. Vol.13, No.3 : 95-101.

Han AR, Min HY, Nam JW, Lee NY, Wiryawan A, Suprapto W, Lee SK, Leenand KR, Seo EK. 2008. Identification of A New Naphthalene and Its Derivatives from The Bulb of Eleutherine Americana with Inhibitory Activity on Lipopolysaccharide-Induced Nitric Oxide Production. Chemical and Pharmaceutical Bulletin. Vol. 56, No. 9 : 1314-1316.

Hara H, Maruyama N, Yamshita S, Hayashi $\mathrm{Y}$, Lee KH, Bastow KF, Chairul, Marumoto R, and Imakura Y. 1997. Elecanacin, A Novel Naphtoquinone from The Bulg Of Eleutherine Americana. Chemical and Pharmaceutical Bulletin. Vol. 45, No. 10 : 1714-1716.

Kuntorini EM, Astuti MD. 2009. Penentuan Aktivitas Antioksidan Ekstrak Etanol Bulbus Bawang Dayak (Eleutherine Americana Merr). Banjarmasin : FMIPA Universitas Lambung Mangkurat.

Lamando D, Soegianto A, Abadi A, Keman S. 2014. Atioxidant Effect of Sarang Semut (Myrmecodia pendens) on The Apoptosis of Spermatogenic
Cells of Rats Exposed to Plumbum. Research Journal Of Pharmautical, Biological And Chemical Sciences. Vol 5, No. 4 : 282-294.

Lubis HS, Sono OP, Lunardhi H, I'tishom R. 2009. Perubahan Motilitas Spermatozoa pada Pria Terpapar Emisi Gas Buang Kendaraan Bermotor. Majalah Andrologi Indonesia No. 23 Desember.

Mardiani HT. 2008. Pengaruh Pemberian Timbal $(\mathrm{Pb})$ terhadap Kadar Malondialdehid (MDA) Plasma Mencit. Tesis. Medan : Universitas Sumatera Utara.

Nawawi A, Winasih R, Anggi A. 2007. Isolasi dan Identifikasi Senyawa Kuinon dari Simplisia Umbi Bawang Sabrang (Eleutherine palmifolia merr). Bandung : Sekolah Tinggi Farmasi Bandung

Nielsen LB \& Wege D. 2006. The Enantioselective Synthesis of Elecanacin Through An Intramolecular Naphtoquinonevenyl Ether Photochemical Cycloaddition. Organic and Biomolecular Chemistry. 4: 868-876.

Palar H. 2008. Pencemaran dan Toksikologi Logam Berat. Jakarta: Rineka Cipta.

Patocka J \& Cerny K, 2003. Inorganic Lead Toxicology, Review Article. Acta Medica. Vol. 46, No. 2 : 65-73.

Patrick L. 2006. The Role of Free Radical Damage and The Use Of Antioxidants in The Pathology and Treatment of Lead Toxicity. Alternative Medicine Review. Vol. 11 , No. 2 : 114-127.

Prior RL \& Schaich K. 2005. Standardized Methods for The Determination of Antioxidant Capacity and Phenolics in Foods and Dietary. Journal Agric Food Chemistry. Vol. 9 No. 2.

Sharma R \& Garu U. 2011. Effects of Lead Toxicity on Developing Testes in Swiss Mice. Universal Journal of Environmental Research and Technology. Vol. 1, Issue 4: 390398.

Sokol RZ, Wang S, Wan YJ, Stanczyk FZ, 
Jurnal Biosains Pascasarjana Vol. 19 (2017) pp

(O(2017) Sekolah Pascasarjana Universitas Airlangga, Indonesia

Gentzschein E, Chapin RE. 2002. Long-term, low-dose lead exposure alters the gonadotropin - releasing hormone system in the male rat. Environ Health Perspect. 110 : 871 874

Verstraeten SV, Aimo L, Oteiza PI. 2008.

Aluminium and Lead : Molecular Mechanism of Brain Toxicity. Archive Toxicology. Vol. 82. 